\title{
INHIBITIVE BEHAVIOUR OF GREEN INHIBITOR IN POTABLE WATER DISTRIBUTION SYSTEM
}

\author{
T. Asokan, C.Thangavelu \\ Department of chemistry, Govt. Arts College, Tiruchirappalli - 22, TN, India. \\ tasok.chemistry71@gmail.com \\ Department of chemistry, Periyar E.V.R. college (Autonomous), Tiruchirappalli-23, TN, India. \\ drkctv@gmail.com
}

\section{ABSTRACT}

The inhibition effect of amino trimethylene phosphonic acid (ATMP) and zinc ions on the corrosion of carbon steel in potable water distribution system was investigated. The corrosion inhibiting action was studied through weight loss, potentiodynamic polarization and AC impedance spectroscopy techniques. The possibilities of formation of protective complex was examined using UV - visible spectroscopy. The investigations revealed that zinc acts as an excellent synergist in corrosion inhibition. UV - visible spectral study indicates that there will be a possibility of formation of complexes of ATMP and $\mathrm{Zn}^{2+}$ with carbon steel iron. Polarization studies indicate that the new binary system is a mixed inhibitor. Result of the impedance studies shows that a protective film is formed on the metal surface in presence of the inhibitor formulation.

\section{Indexing terms/Keywords}

Phosphonic acid; weight loss; synergism; spectral and electrochemical studies

\section{Academic Discipline And Sub-Disciplines}

Chemistry/Electrochemistry

\section{SUBJECT CLASSIFICATION}

Corrosion

TYPE (METHOD/APPROACH)

Experimental study

\section{Council for Innovative Research}

Peer Review Research Publishing System

Journal: Journal of Advances in Chemistry

Vol. 10, No. 3

editorjaconline@gmail.com

www.cirjac.com 


\section{INTRODUCTION}

From economic point of view, obstruction to flow is the major problem due to corrosion products in a potable water distribution system. Increased pumping costs of $\$ 40$ million a year have been estimated to result from obstruction of flow by corrosion products [1]. Corrosion of water heaters poses a much more expensive problem. Replacement costs have been estimated at $\$ 300$ million a year [1]. Potable waters vary quite widely in composition. Dissolved solids range from about $20 \mathrm{mg} / \mathrm{l}$ to over $2 \mathrm{~g} / \mathrm{l}$. Over 100 public supplies exceeded $2 \mathrm{~g} / \mathrm{l}$ total solids in 1962 [2]. Dissolved oxygen does not render pure water particularly corrosive, at least at normal temperatures. However, additions of traces of sulphate or chloride (i.e., $0.55 \mathrm{mg} / \mathrm{l}$ ) suffice to make it highly aggressive [3]. Larson and co-workers [4-6] have found that chlorides, sulphates and nitrates stimulate corrosion of iron in oxygen bearing water, while calcium, bicarbonate and hydroxide were inhibitive.

The use of zinc salts with the polyphosphates markedly accelerates the establishment of protection [7-9]. Zinc repair also is accelerated by zinc which may be incorporated in the phosphate glass or may be fed separately as a soluble salt. Optimum zinc and polyphosphate dosages are somewhat interdependent. Higher zinc levels and vice versa. However, zinc dosages generally are fixed at a definite percentage (i.e., between 9 and 10\%) of the polyphosphate feed. Thus, the normal operating level of zinc is well below the allowable limit $(5 \mathrm{mg} / \mathrm{l}$ or $5 \mathrm{ppm})$ for a potable supply [2]. Since the polyphosphate in the reason for microbial corrosion and conversion into orthophosphate, an alternate is needed. Though many inhibitors are available the selective is limited by considering the portability.

The present work was designed to study the corrosion inhibition of carbon steel in potable water by ATMP and zinc ions as corrosion inhibitors using three different techniques: weight loss, electrochemical studies and UV - visible spectroscopy techniques, hoping to get some general ideas to guide the composing of inhibitor in reality.

\section{EXPERIMENTAL DETAILS}

\subsection{Materials}

The composition of carbon steel used for corrosion inhibition studies was (Wt \%): $0.026 \% \mathrm{~S}, 0.06 \% \mathrm{P}, 0.4 \% \mathrm{Mn}, 0.1 \% \mathrm{C}$ and balance being Fe. The specimens of size $1.0 \mathrm{~cm} \times 4.0 \mathrm{~cm} \times 0.2 \mathrm{~cm}$ were press cut from the carbon steel sheet, were machined and abraded with a series of emery papers.

This was followed by rinsing in acetone and bidistilled water and finally dried in air. Before any experiment, the substrates were treated as described and freshly used with no further storage. The inhibitors ATMP, molecular mass $573.20 \mathrm{~g} \mathrm{~mol}^{-1}$, $\mathrm{Zn}^{2+}$ ions were used as received. A stock solution of 1000ppm of ATMP was prepared in bidistilled water and the desired concentration was obtained by appropriate dilution. The concentration of ATMP used for the study ranges from 10 to 150ppm. All solutions were prepared using potable water (Tiruchirappalli, Tamil Nadu, India). The study was carried out at room temperature. The molecular structure of ATMP is given in Fig 1.

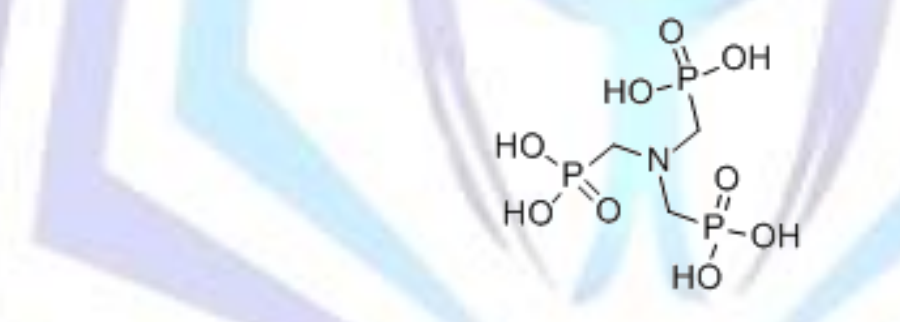

Figure 1. Molecular structure of ATMP

\subsection{Weight - loss Measurements}

The freshly prepared carbon steel specimens were suspended in $150 \mathrm{ml}$ beakers containing $100 \mathrm{ml}$ of test solution maintained at room temperature with the aid of glass rods and hooks. The weight loss taken was the difference between the weight at a given time and the original weight of the specimens. The measurements were carried out for the uninhibited solution and the solution containing ATMP and ATMP - $\mathrm{Zn}^{2+}$ mixture. Weight loss experiments were performed for the duration of seven days. The specimens were immersed in triplicate and the average corrosion rate was calculated. These uncertainties or RSD for three replicate measurements were less than $5 \%$. The corrosion rates $\left(C_{R}\right)$ were determined using the equation:

$$
C R\left(\frac{m m}{y}\right)=\frac{87.6 \times w}{\text { a tD }}
$$

where $\mathrm{w}=$ corrosion weight loss of carbon steel $(\mathrm{mg})$

$$
\begin{gathered}
\mathrm{a}=\text { area of the coupon }\left(\mathrm{cm}^{2}\right) \\
\mathrm{t}=\text { exposure time }(\mathrm{h}) \\
\mathrm{D}=\text { density of the carbon steel }\left(\mathrm{g} \mathrm{cm}^{-3}\right) \text {. }
\end{gathered}
$$


The inhibition efficiency (IE) of ATMP - $\mathrm{Zn}^{2+}$ mixture was calculated by using the following equation:

$$
\% I E=\frac{\mathrm{C}_{\mathrm{Ro}}-\mathrm{C}_{\mathrm{Ri}}}{\mathrm{C}_{\mathrm{Ro}}} \times 100
$$

where $\quad \mathrm{C}_{\mathrm{Ro}}=$ corrosion rate of carbon steel in the absence of inhibitor

$\mathrm{C}_{\mathrm{Ri}}=$ corrosion rate of carbon steel in the presence of inhibitor

\subsection{Electrochemical studies}

Both the potentiodynamic polarization studies and electrochemical impedance spectroscopic (EIS) studies were carried out using the electrochemical workstation model $\mathrm{CHI}-760 \mathrm{~d}$ and the experimental data were analysed by using the electrochemical software (Version: 12.22.0.0). The measurements were conducted in a conventional three electrode cylindrical glass cell with platinum electrode as auxiliary electrode and saturated calomel electrode as reference electrode. The working electrode was carbon steel embedded in epoxy resin of polytetrafluoroethylene so that the flat surface of $1 \mathrm{~cm}^{2}$ was the only surface exposed to the electrolyte.

The three electrodes set up was immersed in control solution of volume $100 \mathrm{ml}$ both in the absence and presence of the inhibitors formulations and allowed to attain a stable open circuit potential (OCP). The $\mathrm{pH}$ values of the solution were adjusted to 7.0 and the solutions were unstirred during the experiments. Polarization curves were recorded in the potential range of -750 to $-150 \mathrm{mV}$ with a resolution of $2 \mathrm{mV}$. The curves were recorded in the dynamic scan mode with a scan rate of $2 \mathrm{mVS}^{-1}$ in the current range of $-20 \mathrm{~mA}$ to $+20 \mathrm{~mA}$. The Ohmic drop compensation has been made during the studies. The corrosion potential $\left(E_{\text {corr }}\right)$, corrosion current $\left(I_{\text {corr }}\right)$, anodic Tafel slope $\left(\beta_{a}\right)$ and cathodic Tafel slope $\left(\beta_{c}\right)$ were obtained by extrapolation of anodic and cathodic regions of the Tafel plots.

Electrochemical impedance spectra in the form of Nyquist plots were recorded at OCP in the frequency range from $60 \mathrm{KHz}$ to $10 \mathrm{MHz}$ with 4 to 10 steps per decade. A sine wave, with $10 \mathrm{mV}$ amplitude, was used to perturb the system. The impedance parameters viz., charge transfer resistance $\left(R_{c t}\right)$, double layer capacitance $\left(C_{d l}\right)$ were obtained from the Nyquist plots.

\subsection{The UV- Visible absorption spectra}

The possibility of formation of $\mathrm{Zn}^{2+}$ - phosphonic acid complex in solutions was examined by mixing the respective solutions and recording their UV -visible absorption spectra using Hitachi U -3400 spectrophotometer.

\section{RESULTS AND DISCUSSION}

\subsection{Weight-loss measurements}

The inhibition actions of ATMP and $\mathrm{Zn}^{2+}$ in controlling corrosion of carbon steel immersed in potable water for a duration of seven days in the both without and with of ATMP and $\mathrm{Zn}^{2+}$ is given in Table 1. It can be seen from data that $\mathrm{Zn}^{2+}$ alone has some IE and ATMP alone is poor inhibitor and is found to be corrosive. For example 150ppm of ATMP has $27 \%$ IE and $5 \mathrm{ppm}$ of $\mathrm{Zn}^{2+}$ has $8 \% \mathrm{IE}$. However the combination of $150 \mathrm{ppm}$ of ATMP and $5 \mathrm{ppm}$ of $\mathrm{Zn}^{2+}$ has $78 \%$ IE. This is found to be the maximum IE obtained by the system. This clearly suggests that ATMP and $\mathrm{Zn}^{2+}$ mutually enhance the inhibition efficiency of each other in controlling the corrosion of carbon steel.

The synergism is due to the formation of complex with ATMP and the role of $\mathrm{Zn}^{2+}$ is to transport the ATMP inhibitor from the bulk of the solution onto the metal surface [10-12]. 
Table 1. Corrosion Inhibition efficiency of carbon steel in potable water system, with and without addition of inhibitor obtained by the weight loss method.

\begin{tabular}{|c|c|c|c|c|}
\hline $\begin{array}{c}\text { Concentration of } \\
\mathrm{Zn}^{2+}(\mathrm{ppm})\end{array}$ & $\begin{array}{l}\text { Concentration of } \\
\text { ATMP (ppm) }\end{array}$ & $\begin{array}{l}\text { Corrosion Rate } \\
\left(C_{R}\right) \mathrm{mmy}^{-1}\end{array}$ & $\begin{array}{c}\text { Inhibition } \\
\text { efficiency } \\
(\%)\end{array}$ & $\begin{array}{c}\text { Surface } \\
\text { coverage }(\theta)\end{array}$ \\
\hline- & - & 311.1 & - & - \\
\hline- & - & 283.9 & 8 & 0.08 \\
\hline- & 10 & 361.7 & -16 & 0.16 \\
\hline- & 25 & 330.6 & -6 & 0.06 \\
\hline- & 50 & 299.4 & 3 & 0.03 \\
\hline- & 75 & 280.0 & 10 & 0.10 \\
\hline- & 100 & 266.4 & 14 & 0.14 \\
\hline- & 125 & 245.0 & 21 & 0.21 \\
\hline- & 150 & 225.5 & 27 & 0.27 \\
\hline 5 & 10 & 280.0 & 10 & 0.10 \\
\hline 5 & 25 & 233.3 & 25 & 0.25 \\
\hline 5 & 50 & 194.4 & 37 & 0.37 \\
\hline 5 & 75 & 157.5 & 49 & 0.49 \\
\hline 5 & 100 & 134.1 & 57 & 0.57 \\
\hline 5 & 125 & 105.0 & 66 & 0.66 \\
\hline 5 & 150 & 66.1 & 78 & 0.78 \\
\hline
\end{tabular}

\subsection{Influence of duration of immersion on the inhibition efficiency of $\mathrm{Zn}^{2+}$ and ATMP system.}

When $5 p p m \mathrm{Zn}^{2+}$ is added to the various ATMP concentrated solution, there is a increase in I.E in particular day but when Time Period increases I.E also decreases due to desorption of protective complex into bulk.

Table 2. Influence of immersion period on the IE and corrosion rate of ATMP $-\mathrm{Zn}^{2+}(5 \mathrm{ppm})$ system

\begin{tabular}{|c|c|c|c|c|c|c|c|c|c|}
\hline \multicolumn{2}{|c|}{ Duration } & \multicolumn{2}{|c|}{$\mathbf{3}$} & \multicolumn{2}{c|}{$\mathbf{3}$} & \multicolumn{2}{c|}{7} \\
\hline $\begin{array}{c}\text { Con. } \\
\text { Of } \\
\mathbf{Z n}^{2+} \\
(\mathbf{p p m})\end{array}$ & $\begin{array}{c}\text { Con. } \\
\text { Of } \\
\text { ATMP } \\
(\mathrm{ppm})\end{array}$ & $\begin{array}{c}\mathbf{C}_{\mathrm{R}} \\
\mathbf{m m y}^{-1}\end{array}$ & $\begin{array}{c}\text { IE } \\
(\%)\end{array}$ & $\begin{array}{c}\mathbf{C}_{\mathrm{R}} \\
\mathbf{m m y}^{-1}\end{array}$ & $\begin{array}{c}\text { IE } \\
(\%)\end{array}$ & $\begin{array}{c}\mathbf{C}_{\mathrm{R}} \\
\mathbf{m m y}^{-1}\end{array}$ & $\begin{array}{c}\text { IE } \\
(\%)\end{array}$ & $\begin{array}{c}\mathbf{C}_{\mathrm{R}} \\
\mathbf{m m y}^{-1}\end{array}$ & $\begin{array}{c}\text { IE } \\
(\%)\end{array}$ \\
\hline- & - & 5.8 & - & 70.0 & - & 138.9 & - & 311.1 & - \\
\hline 5 & 10 & 5.0 & 14 & 60.0 & 14 & 104.1 & 25 & 280.0 & 10 \\
\hline 5 & 25 & 4.4 & 23 & 56.6 & 19 & 93.0 & 33 & 233.3 & 25 \\
\hline 5 & 50 & 3.8 & 33 & 50.0 & 28 & 76.4 & 45 & 194.4 & 37 \\
\hline 5 & 75 & 3.3 & 42 & 45.0 & 36 & 70.8 & 49 & 157.5 & 49 \\
\hline 5 & 100 & 2.5 & 57 & 29.1 & 58 & 59.7 & 57 & 134.1 & 57 \\
\hline 5 & 125 & 1.6 & 71 & 17.5 & 75 & 43.0 & 69 & 105.0 & 66 \\
\hline 5 & 150 & 0.5 & 90 & 10.8 & 84 & 27.7 & 80 & 66.1 & 78 \\
\hline
\end{tabular}




\subsection{Potentiodynamic Polarization study}

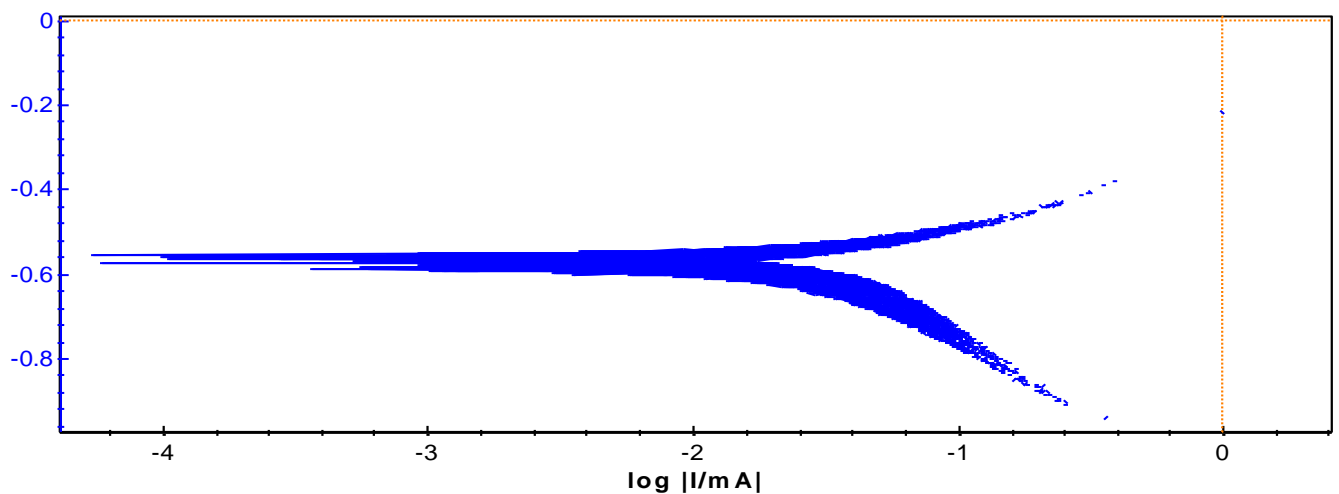

Figure 2a. Without inhibitor

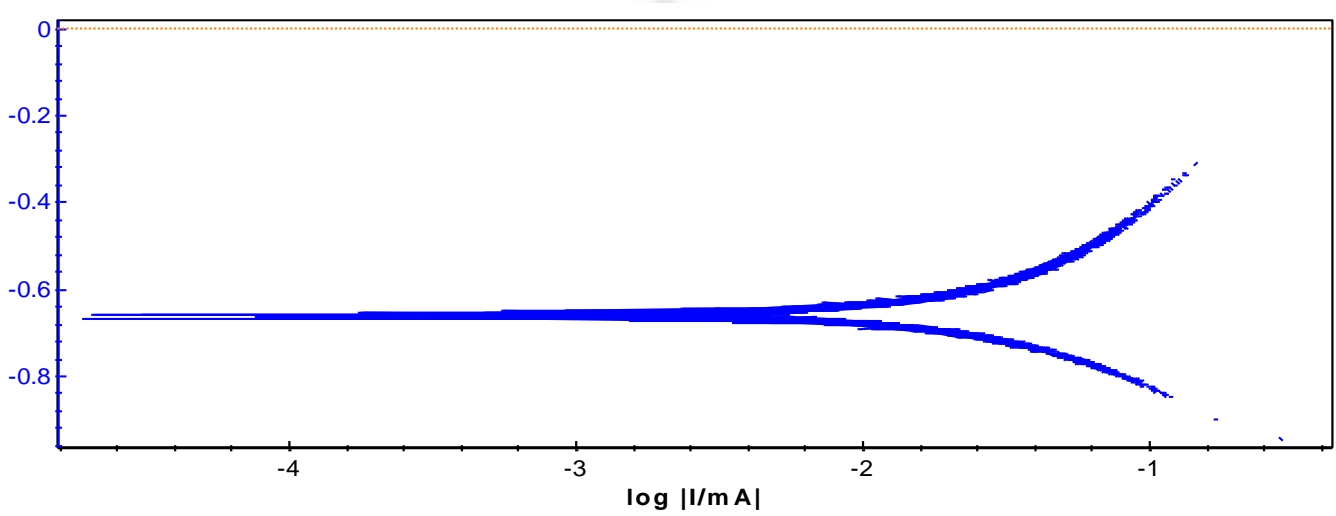

Figure 2b. With inhibitor (5ppm $\mathrm{Zn}^{2+}+150 \mathrm{ppm}$ ATMP)

Show polarization curve of carbon steel in potable water without and with of inhibitor. It was found that the values of corrosion current density $\left(I_{\text {corr }}\right)$ of carbon steel in the potable water with inhibitor were smaller than without addition of inhibitor.

Furthermore, as presented in Fig. $2 b$. the addition of $5 p p m \mathrm{Zn}^{2+}+150 \mathrm{ppm}$ ATMP shifts the corrosion potential $\left(\mathrm{E}_{\text {corr }}\right)$ value $(-625.045 \mathrm{mV}$ to $-646.094 \mathrm{mV})$ in presence inhibitor according to Ferreira and W.H. Li if the displacement in corrosion potential is more than $85 \mathrm{mV}$ with respect to the corrosion potential of the blank, the inhibitor can be seen as cathodic or anodic type [13-14]. The maximum displacement was $<21 \mathrm{mV}$ which indicated that the studied inhibitor and the effect is more evident at higher concentrations. These results suggest that the studied formulation can be classified as mixed type inhibitor.

Table 3. Tafel parameters for carbon steel in potable water system in without and with addition of inhibitors

\begin{tabular}{|c|c|c|c|c|c|c|}
\hline S.No & $\begin{array}{c}\text { Conc. Of } \mathbf{Z n}^{2+} \\
(\mathbf{p p m})\end{array}$ & $\begin{array}{c}\text { Conc. Of ATMP } \\
(\mathbf{p p m})\end{array}$ & $\mathbf{E}_{\text {corr }} \mathbf{m V}$ & $\mathbf{I}_{\text {corr }} \mathbf{m V}$ & $\boldsymbol{\beta}_{\mathbf{a}} \mathbf{m V}$ & $\boldsymbol{\beta}_{\mathbf{c}} \mathbf{m V}$ \\
\hline 1 & Blank & - & -625.04 & 31.79 & 228.6 & 221.3 \\
\hline 2 & 5 & 150 & -646.09 & 19.95 & 296.7 & 258.9 \\
\hline
\end{tabular}




\subsection{AC Impedance Spectra}

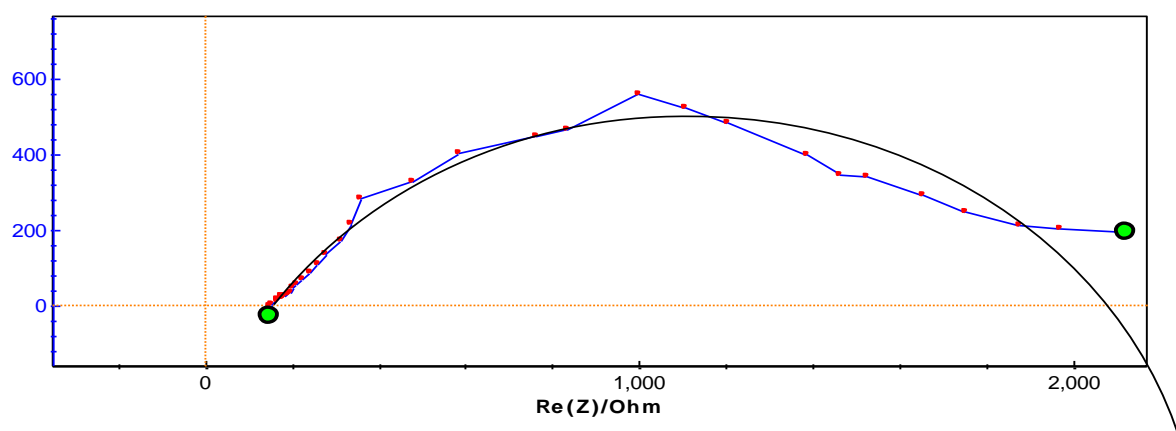

Figure 3a. Without inhibitor

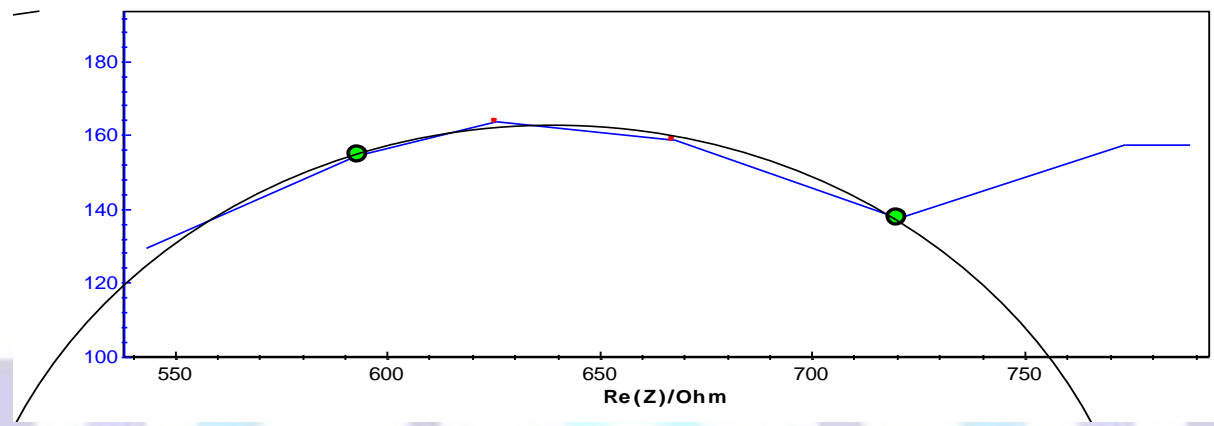

Figure 3b. With inhibitor (5ppm $\mathrm{Zn}^{2+}+150 \mathrm{ppm}$ ATMP)

The Nyquist plots of carbon steel immersed in potable water is shown in Fig. 3a. and Fig. 3b. The Nyquist parameters namely, charge transfer resistance $\left(R_{c t}\right)$ and double layer capacitance $\left(C_{d l}\right)$ are given in Table 4 . Without inhibitor system, the low $R_{\mathrm{ct}}$ value and higher $\mathrm{C}_{\mathrm{dl}}$ value and with inhibitor system, the high $\mathrm{R}_{\mathrm{ct}}$ value and lower $\mathrm{C}_{\mathrm{dl}}$. These values confirm that the formation of a protective film onto the metal surface.

Table 4. Nyquist parameters for carbon steel in potable water system in without and with addition of inhibitors.

\begin{tabular}{|c|c|c|c|c|}
\hline S.No & Conc. of $\mathrm{Zn}^{2+}(\mathrm{ppm})$ & $\begin{array}{l}\text { Conc. of ATMP } \\
\text { (ppm) }\end{array}$ & $\mathbf{R}_{\mathrm{ct}}(\mathrm{ohm})$ & $\begin{array}{c}C_{\mathrm{dl}} \\
\text { F.cm } \\
-2 \times 10^{-6}\end{array}$ \\
\hline 1 & Blank & - & 276.5 & 16.05 \\
\hline 2 & 5 & 150 & 1919 & 1.23 \\
\hline
\end{tabular}

\subsection{Analyses of UV-visible spectra}

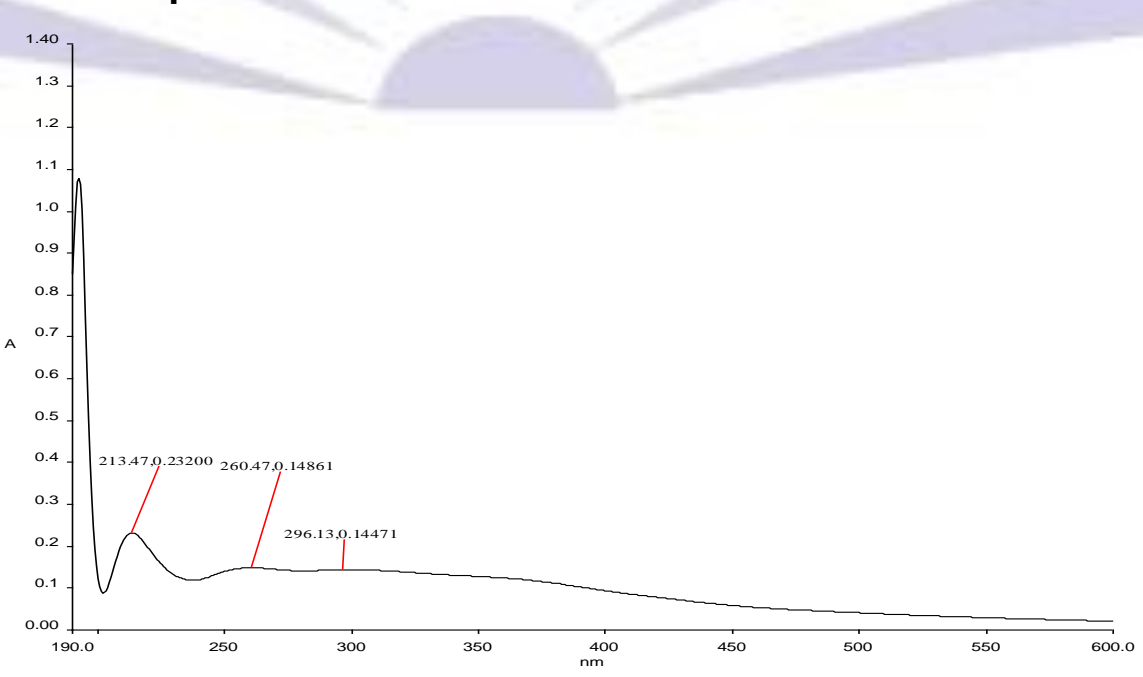

Figure 4. Without Inhibitor 


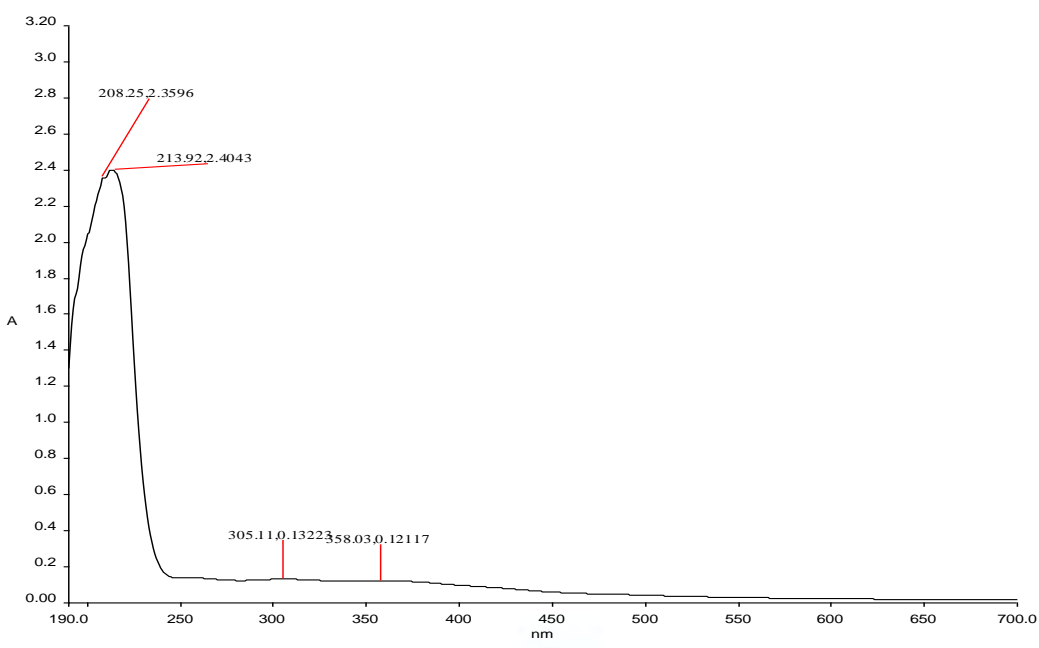

Figure 4a. With inhibitor (5ppm $\mathrm{Zn}^{2+}+150 \mathrm{ppm} \mathrm{ATMP}+100 \mathrm{ppm} \mathrm{Fe} \mathrm{Fe}^{2+}$ )

UV- visible absorption spectra can be used to confirm the possibility of formation protective film on the metal surface [1516]. UV- visible absorption spectrum of ATMP and $\mathrm{Zn}^{2+}$ is shown in Fig.4. A remarkable increase in absorbance is noticed in Fig. 4a than in Fig. 4b. These observations indicate that there is a formation of $\mathrm{Zn}^{2+}-\mathrm{ATMP}$ complex and Fe $\mathrm{Fe}^{2+}-\mathrm{ATMP}$ complex in solution.

\section{CONCLUSION}

The following main conclusions are drawn from the present study:

$>$ The binary formulation ( $5 \mathrm{ppm} \mathrm{Zn}^{2+}$ and 150ppm ATMP) has good inhibition effect for the corrosion of carbon steel in potable water system.

$>$ Significant synergism was attained by the combined application of $5 \mathrm{ppm} \mathrm{Zn}^{2+}-150 \mathrm{ppm}$ ATMP system

$>$ Polarization data showed that the investigated inhibition formulation acts as a mixed type inhibitor.

$>A C$ impedance spectra reveal that a protective film is formed onto carbon steel surface

$>$ UV-visible spectral study indicates that there was a possibility of formation of complexes.

$>$ This new inhibitor formulation is more eco- friendly.

\section{REFERENCES}

[1] Lichtenstein, S. The Many Faces of Corrosion. Tech. News. Nat. Bur. Stand., U.S. Dept. of Commerce. STR-3454, Oct 1966. Materials Protection, 6, 29 (1967) April.

[2] Public Health Service Drinking Water Standards-1962. Public Health Service Publ. No. 956,

[3] Hatch, G. B. and Rice, O. Influence of Water Composition of the corrosion of steel. J. AWWA, 51, 719-727 (1959) June.

[4] Larson, T. E. and King, R.M. Corrosion by water at low flow Velocity. J. AWWA, 46, 1-9, (1954) January.

[5] Skold, R.V. and Larson, T.E. Measurement of the Instantaneous Corrosion Rate by Means of Polarization Data. Corrosion, 13, 139t-142t (1957) February.

[6] Larson, T.E. and Skold, R.V. Laboratory Studies Relating Mineral Quality of Water to Corrosion of Steel and cast Iron. Corrosion, 14, 285t-288t (1958) June.

[7] Hatch, G.B. and Rice, O. Threshold Treatment of water system. Ind. Eng. Chem., 37, 710- 715 (1945) August.

[8] Hatch, G.B. Control of Couples Developed in Water systems. Corrosion, 11, 461t-468t (1955) November.

[9] Hatch, G.B. and Ralston, P.H. Oxygen corrosion control in flood water waters. Mat. Pro., 3, 35-41 (1964) August.

[10] Chinnaiyan Thangavelu and Thavan kasilingam. Electrochemical and surface modification studies of green materials. Chem. Sci. Rev. Lett. 3(9), 10-17, 2014.

[11] Kasilingam, T. and Thangavelu, C. Nano Analyses of protective film onto carbon steel. Inter. J. of Innov. Tech. and Expl. Engin. Volume-3, Issue-12, May 2014. 
[12] Thangavelu, C., M.Umarani, M. Sekar, "Eco- Friendly Inhibitor System for Corrosion Inhibition of Carbon Steel in High Chloride Media", RASAYAN.J.Chem. 4(2011)245-250.

[13] Ferreira, E.S., Giacomellic, C., Giacomellic,F.C., and Spinelli, A., Mater. Chem. Phys, 83 (1), 129-134 (2004)

[14] Li, W.H., He, Q., Pei, C.L., and Hou, B.R., J. Appl. Electrochem, 38 (3), 289 - 295 (2008).

[15] Thangavelu. C, Patric Raymond. P, Rajendran. S, Sundaravadivelu. M, "Influence of Chloride lon on the Corrosion Inhibition Efficiency of the ATMP-Zn ${ }^{2+}$ System," Asian j. Research Chem. 4(3)(2011)402-405.

[16] Rajendran. S, Thangavelu. C, Venkatesh. T, "Study of Synergistic Effect of Diethylene triamine Penta(methylene phosphonic acid) and Adipic acid on the Inhibition of Corrosion of Alkaline Aluminium," Der Chemica Sinica, 3(6)(2012)1475-1485. 